Rev Biomed 2005; 16:293-294.

\title{
Breve consideración sobre la eutanasia.
}

Carta al Editor

Jesús Quintanilla-Osorio.

Servicios Estatales de salud de Quintana Roo. Coordinación de Regulación Sanitaria,Chetumal, Quintana Roo, México.

La controversia sobre la llamada muerte asistida, comúnmente conocida como eutanasia, busca definir el supuesto derecho del individuo con una enfermedad terminal de decidir cuándo poner término a su vida.

Los debates en torno a este tema, deben considerar todas las implicaciones éticas y morales que el caso supone, así como las experiencias recogidas por el estudio de la historia en situaciones con aspectos similares. En el ámbito histórico, es preciso recordar la crueldad demostrada en los campos de concentración reflejada en libros como "Yo fui médico del diablo" de Karl Von Vereiter, o "Los hornos de Hitler" de Olga Langeley, y la actuación en esta época contemporánea del llamado "Doctor Muerte", responsable de decenas de "muertes asistidas", antes de pensar en autorizar una ley a favor de la eutanasia.

Si bien los promotores del "derecho a morir" se pronuncian sobre evitar el dolor de quienes padecen una enfermedad terminal por considerarlo una tortura innecesaria, los detractores señalan los inconvenientes éticos y morales de apoyar una práctica que de por sí atenta contra la continuidad de la especie humana. "La muerte", escribió Robert Hertz, "no se limita a poner fin a la existencia corporal de un ser vivo, si no que del mismo golpe destruye al ser social inserto en la individualidad física" (1).

Los practicantes del ejercicio médico, obligados a cumplir el juramento hipocrático de defender el derecho a la vida, deben agotar todo el cúmulo de posibilidades, antes de decidir si el paciente en cuestión tiene la capacidad mental de definir su propio destino, con las consecuencias legales de participar como "asistente" en la muerte de quienes deben defender, porque como señala Jean Rostand, citando a F. Lhermitte, "hay esperanza de vida mientras que manifestaciones motrices atestiguan la persistencia funcional de un sistema nervioso vivo, mientras la vida vegetativa continúe"(2). Sumado a esto, la inescrupulosidad

Solicitud de sobretiros: Jesús Quintanilla-Osorio. Tlaxcalaltongo No. 250 entre Carranza y San Salvador, Col. Venustiano Carranza, C.P. 77012, Chetumal, Quintana Roo, México. Correo electrónico: jesusin06_@hotmail.com

Recibido el 10/Junio/2005. Aceptado para publicación el 22/Junio/2005. 


\section{J Quintanilla-Osorio.}

humana como un cáncer cada vez más presente en el tejido social, obliga a pensar si la existencia de una ley sobre la eutanasia, con los vacíos legales que entraña toda legislación perfectible, no serviría para dar cabida a personajes de siniestro talante, dispuestos a ejercer, a cambio de unas monedas, juicios sumarios donde los pacientes terminales fueran víctimas de mentes desquiciadas. La"muerte asistida" no debe ser parte de un hueco legal, y, como la clonación de seres humanos, implica un alto costo social que destruye los cimientos de la vida misma, por lo cual, es indispensable estudiar detenidamente su aplicación, antes de imaginar siquiera la mera posibilidad de meterla a discusiones buscando su autorización.

Palabras clave: Eutanasia, muerte.

\section{REFERENCIAS.}

1.- Hertz R. La muerte. La mano derecha. $1^{a}$ Ed. México: Alianza Editorial Mexicana; 1990. p. 89.

2.- Rostand J. Ensayos sobre lo humano. $1^{\text {a }}$ Ed. México: Alianza Editorial; 1994. p. 68. 